\title{
Metasomatism of crust-mantle boundary by melts derived from subducted sedimentary carbonates and silicates
}

\author{
JUN HU ${ }^{1}$ NENG JIANG ${ }^{2}$
}

${ }^{1}$ Institute of Geology and Geophysics, Chinese Academy of Sciences, Beijing 100029, China. hujun0620@126.com

${ }^{2}$ Institute of Geology and Geophysics, Chinese Academy of Sciences, Beijing 100029, China.

jiangneng@mail.iggcas.ac.cn

Substantial quantities of sediments are known to enter the deep lithosphere at subduction zones, but little is known about the extent to which sediments melt and the process involved in sediment contribution to the deep lithosphere. Vigorous debate continues whether the sediment component is terrigenous or pelagic and transported as a hydrous melt, an aqueous fluid, or bulk sediment. Here, we conduct an integrated study on a variety of deep-seated xenoliths in the Neogene Hannuoba basalts from the northern margin of the North China Craton. Among these xenoliths, clinopyroxenite xenoliths are compositionally and isotopically distinct. Mineral chemistry shows that the clinopyroxenite xenoliths come from a depth near the MOHO, rather than from the mantle as suggested previously. The clinopyroxenite xenoliths have extremely evolved $\mathrm{Sr}-\mathrm{Nd}-\mathrm{Hf}$ isotopic compositions and have a late Archean protolith age. The occurrence of hydrous minerals and high contents of LILE (K, $\mathrm{Rb}, \mathrm{Ba}, \mathrm{Th}$ and $\mathrm{Sr})$ and LREE, as well as elevated $\delta^{18} \mathrm{O}(9.9-$ $11.3 \%)$ and light $\delta^{26} \mathrm{Mg}(-1.04 \%$ o to $-1.42 \%$ ) isotopic compositions strongly support a metasomatic origin. Furthermore, their high HFSE (Nb, Ta, $\mathrm{Zr}$ and $\mathrm{Hf}$ ) contents indicate that the metasomatic agent is a hydrous melt, rather than an aqueous fluid. The metasomatic melts are considered to be derived from a mixed source of sedimentary carbonates and ancient, felsic continental materials. A combination of zircon ages and oxygen isotope data for the clinopyroxenite xenoliths further restricts the timing of metasomatism to the late Paleozoic. Considering the regional tectonic setting, the sediments most likely came from the subducted Paleo-Asian oceanic slab. The data show that melting of subducted sediments can take place at a much shallower depth $(\sim 45 \mathrm{Km})$ than commonly thought and place an independent constraint on future models of slab geotherms. 